\title{
STIMULATING ENVIRONMENT IN MEETING THE NEEDS OF DEAF CHILDREN OF PRESCHOOL AGE
}

\author{
Prof. Nevenka Tatković, PhD \\ Juraj Dobrila University of Pula (Croatia) \\ Department of Educational sciences \\ e-mail: ntatkovic85@gmail.com \\ Aida Muradbegović, MA \\ Juraj Dobrila University of Pula (Croatia) \\ Department of Educational sciences \\ e-mail: aida.muradbegovic@ optinet.hr \\ Marija Crnčić-Brajković, BA \\ Juraj Dobrila University of Pula (Croatia) \\ Department of Educational sciences \\ e-mail: crncicbrajkovic@yahoo.it
}

\section{S u m m ary}

Early development and acquisition of experience takes place through communication, in space and time. These factors are specific for deaf children and can create disturbances in the structuring of their personality.

One area of personality affects the whole development. Therefore, a comprehensive approach to the education of deaf children of preschool age is the principle of education for the protection of equal rights to education of minority culture.

Scientific researches have shown that deafness itself does not adversely affect the development of the child's social, emotional and cognitive abilities, but lack of communication can cause problems in all areas of development. The phenomenon of deafness is not a limiting factor. Some deaf people have reached the top results in various fields of science, art and creativity.

Besides the theoretical approach, this paper presents the results of an empirical research of students' / future preschool teachers' attitudes and opinions about the status of deaf children in society and their integration into regular pre-school institutions.

The results of the research show the presence of a number of prejudices and a certain level students' disbelief in the need for integration of deaf children into regular preschool institutions. The need for the development of preschool teachers' competencies for working with children with special needs in the spirit of the documents which proclaim the right to education has not been recognised yet. 
Key words: stimulating environment, deaf child of preschool age, students, bilingual-bicultural training, preschool teachers' competences.

\section{How understanding of the deaf persons' position in society developed}

Bringing up and educating a deaf child in interfamilial and extra-familial environment raises a series of questions which are directly linked to research on status of persons with special needs at the brink of 21st century.

In the past, persons with special needs were a discriminated social group. It was a long and thorny road for deaf persons while the society's relationship towards them was developing. From denying them any value and right whatsoever, society gradually evolved into ignoring them, tolerating them, showing them charity, stigmatizing them, to proclaiming their integration as a means of social acknowledgement (Carver, 1999).

The deaf persons were thrown at the margins of all events, where they were usually assigned a subordinate juridical, social, political and economic role.

In the last two hundred years the society's relationship towards persons with special needs has seen a lot of changes, developing towards a genuine and general civilized equality (Žunić, 2001).

On the territory of today's Croatia, there aren't many data on the position of persons with damaged hearing. The beginnings of social care are connected with the opening of the first schools for this population.

The first training programme organized for deaf and hearing impaired persons started in 1902 with the objective of offering assistance to students of the National Institute for Deaf-and-Dumb Children in Zagreb (Juriša, 1994). For a long period after that, education of deaf children took place in special educational institutions.

The position of persons with special needs (deaf persons) in society is a burning issue today, and it pertains to their fundamental rights to a stimulating environment. Stimulating environment above all implies appropriate education as a necessary condition for achieving social integration and their further inclusion in the work process. However, only passing laws which regulate the rights of persons with damaged hearing, equivalent to those in the rest of the world, does not guarantee a solution to their problems.

"Normal development", appropriate to the individual's age and needs, is closely linked to regular early cognitive, emotional and social development. However, deaf persons experience this early development mostly within family and a smaller community, which excludes the influence of a wider social environment, engaging deaf persons in some sort of a vicious circle. For that reason, key problems related to the position of deaf children in society pertain, above all, to the need to define more clearly their development needs and possibilities. In the early childhood, the period of greatest sensitivity, a stimulating environment for deaf children should be considered within the context of determining the etiology and the degree of damage caused by deafness by 
adopting a personalized approach to each child and parent, but resorting also to a systematic pedagogical and educational support, which, due to the complexity of the problem, commands a multidisciplinary approach and treatment (Ivasović, 2007).

Difficulties experienced by deaf persons in spoken language communication have adverse effects on educational achievements of deaf children in school environment. Disparities between intelectual potentials of deaf children and their educational achievements are caused by their poor knowledge of the language used by the majority, and especially by their difficulty in receiving the information. Research indicates that the majority of deaf children up to the age of 18 possess the linguistic knowledge (reading and writing) of a hearing child of 10 (Pribanić, 1995). Moreover, after finishing school they don't go on to perfect their reading skills.

Recent research and experience prioritizes bilingual pedagogical and educational programs (bilingual-bicultural training) for the deaf, supporting this new model of pedagogical-educational integration over the traditional approach (Bradarić - Jončić and Tarczay, 2004, Neal Mahshie, 1995).

In Croatia, within the context of present situation, an attempt is being made to accommodate the requirements of the traditional models of integration of deaf persons, based on the oral approach, along with the requirements contained in modern models of bilingual-bicultural education of the deaf. "Such integration, as a rule, implies the so called co-teaching (team-teaching, cooperative teaching) model, where next to the regular teacher in teaching there is active participation of the sign language interpreter and the teacher for deaf children" (Bradarić-Jončić and Tarczay, 2008, 108).

Today, the sign language as the first language of the deaf minority in a number of world countries enjoys a status equal to that of any other language of human communities. The European Union Parliament adopted a Sign Language Resolution in 1988 , in which it is emphasized that sign languages are the real natural languages of deaf people. Along the same lines, in 2001 the Council of Europe issued a recommendation to its member countries, and in 2002 Slovenia officially recognized sign language as the language of the deaf minority. Croatia adopted the Council of Europe Recommendation on the protection of national sign languages passed in Strasbourg in March 2003. In this document it is stated that sign languages are an expression of the European cultural heritage, that the member countries officially recognize sign language as a minority language, that the questions related to interpreters' work and their training are regulated, and it specifically emphasizes the role of the sign language in education of deaf children and in teacher training of deaf children.

When it comes to identifying the situation in preschool and elementary school education for the purposes of elaboration of development strategies of the National curriculum of the Republic of Croatia in the context of globalisation and European integration processes, among others, some deficiencies have been identified regarding the definition of the plan and programme for children with special needs, and, more specifically, the need to define the sign language for children with impaired hearing and speech. Regarding general and specific goals and principles, the changes made to the national curriculum focused on defining the fundamental role of preschool education 
and "creating the conditions for comprehensive development of child's personality, enhancing the quality of child's growth and development process and, indirectly, the quality of family life", as well as on "education and training focused on the individual development of the pupil" (Strategies for elaboration and development of the national curriculum, 2007, p. 12, 15 and 18).

\section{A deaf child in family environment and in preschool institution}

It is a well-known fact, that the family environment dynamics is the most important prerequisite for a successful development of every child. Even though there are other factors responsible for their adequate development, represented in particular by their peers, nobody is able to give the kind of physical, social and emotional care and support to the child as their family (Rosić and Zloković, 2002).

The question arises on how the parents of deaf children are managing their parental role. According to some authors, when expecting a child, both deaf and hearing parents expect to have a hearing child. However, hearing parents find it more difficult to accept the child's deafness (Mahshi, 2007). After having gradually adjusted to the new situation, besides the unavoidable hope, parents are faced with a long and very demanding process of establishing communication with their deaf child. The first and most difficult task is finding the will to accept and adjust to the situation, while the second important step is the creation of a positive family environment which would stimulate the child to learn the first language. Parents need expert assistance along this road. For some parents, emotional support is most important, others look for more detailed information on the problem of deafness and possible technical aids, some parents expect pedagogical counselling, and others still want to learn the sign language in order to be able to teach it to their child.

\section{Principles of language learning in the family environment}

Verbal language is a privilege of human beings and it is structured during the first three years of life. In order for this complex process to develop, the pre-requisites are a normal degree of development of the central nervous system, environmental stimulation, an unimpaired hearing system and speech apparatus as well as a healthy neuron connection. Neuron connections in the brain are developed during the earliest years, which is a prerequisite for developing specific higher functions and speech. After this period, spontaneous speech development is much more difficult (Venturini, 2003).

The cries present since birth, spontaneous at the outset, and intentional later on, are the only means with which the child expresses his/her needs in the beginning. After the third and fourth week the child begins to smile, which induces a pleasant feeling in the child in the seventh month of life. The child's vocalisation around the second month is actually a monotonous exercise of organs which are to produce speech in the future. In the fifth month, the child begins to babble by repeating consonants $(\mathrm{m}, \mathrm{b}, \mathrm{p})$, which 
are later to be combined with vowels in the continuous and spontaneous practicing of sound emission and listening.

Only at the age of one, the child begins to intentionally imitate what he/she heard, uttering its first simple words. At one year and a half, the child's vocabulary counts around 50 words, and around the age of two he/she begins to build two-word sentences. Between the second and third year of age, the child is gradually trying to structure ever more complex sentences, making grammar mistakes. At the age of three and four, the child expands his/her sentences by inserting adjectives, questions and commands. By the time child reaches the age of five, his/her language is already well organized.

There are no principles described regarding language development in deaf children. They do not babble which excludes the possibility of qualitative changes in psycho-motor development and language learning (Venturini, 2003). The deaf child's communication with the mother is reduced to the senses of touch and sight. Deciphering mother's moods is possible only on the basis of her emotional attitude and her facial expression, without the aid of speech. Such difficulties cause problems in the social, emotional and cognitive aspect of the child's development, which parents/carers often fail to assign to the deficit (deafness) and are not able to adequately help the child in overcoming the handicap. Both the parents and the deaf child should be provided as early as possible with the multidisciplinary approach in diagnosis and treatment of the child's difficulties. This process should also involve a team of experts: medical doctor pediatrician, social worker, speech pathologist, psychologist, sign language interpreter.

\section{Preschool institution in the deaf child's education}

Early and pre-school age is critical for the development of child's personality, because that is the time when the abilities are most intensely developed and the foundations of emotional development and social identity are laid down.

A child is a unique, holistic human being whose development should touch on all aspects (psycho-motor, cognitive and socio-emotional), even though this division is merely conditional. Each aspect affects the whole and, for this reason, a holistic approach in raising children of early and preschool age should be an educational principle for securing the rights of all children (National programme for education in the field of human rights and democratic citizenship, 1999).

At an early age, the child's deafness causes serious difficulties in the speech learning process, as well as in the child's overall psychophysical development. Child's early learning happens through communication in space and time. The deaf child's sensory limitations make normal development of its personality more difficult. In the light of these facts, one can see the importance of early integration of the deaf child in a systematically organized extra-familial education system for raising the child and stimulating its socialization.

Timely inclusion of deaf children into a preschool institution with other children is of great importance for their successful overcoming of difficulties in learning spoken 
and sign language (Ivasović, 2007). The first three years are equally important in the life of a deaf child, as the crucial period for sign and spoken/written language learning.

The greatest challenge for every deaf child is learning the language of their community. On the other hand, children tend to learn the sign language easily, unconsciously complete, just as hearing children learn the spoken language of their community (Neal Mahshie, 1995). More recent research has supported positive correlation of early bilingualism with social skills and school success of deaf children (Ivasović, 2007). In our opinion, these indicators can contribute to understand better the attitude on the integration of deaf children in the majority social group, with an adequate pedagogical treatment adjusted to the child's needs and abilities in the framework of the organized pre-school education.

\section{Questionnaire conducted on students/future preschool teachers on the position of the deaf in society and integration of deaf children into preschool institutions}

The most recent views and experiences from countries all over the world have contributed significantly to the change in attitude, going in the direction of securing equal education opportunities for persons with special needs. The change in understanding the status of children and young people with special needs in relation to their right to education is shaking traditional educational systems and related attitudes and is inevitably leading to their restructuring at all levels.

In the field of pedagogical disciplines, there is a greatly felt need for acquiring new knowledge, structuring new disciplines, defining new professions, as well as a new approach to the organization of curricula, in which openness to new knowledge and introducing new competencies in the existing study programmes become quality criteria.

A particularly significant role in the democratisation of education should be played by institutions for education of primary school and preschool teachers. National curriculum strategies and legal acts are merely a starting point in understanding the democratic principles regarding equal rights to education for all members of society. General goals and tasks should be more clearly defined in the curriculum of the university education system for primary school and pre-school teachers, in order to develop new material and new competencies of future primary school and pre-school teachers. In these conditions, primary school and pre-school teachers can be competent partners within the integrated education system, and by team work they can become active partners for sign language interpreters and deaf children teachers.

The Department of Educational Sciences of Juraj Dobrila University in Pula has had some positive experience in the integration of persons with disabilities in the preschool teachers' education system, even though the process was often difficult.

To the statistics published in the Croatian expert magazines, we are proud to add one more disabled person who graduated from the preschool teaching course at the 
Department of Educational Sciences of Juraj Dobrila University in Pula in the academic year 2009/10, as well as a female student with disability (also deaf), who is attending the second year of the preschool teaching course.

In the context of current issues related to the integration of persons with disabilities in the university system, an opinion pole was conducted on students'/future preschool teachers' concerning their perception of the status of deaf persons in society and the integration of deaf children in regular preschool institutions. Deliberate sample covered respondents/students of all years of preschool teaching studies $(\mathrm{N}=70)$. The survey was conducted in February 2010 and it represents the empirical part of the thesis of the female student with disability. The questionnaire was anonymous, and the questions were posed in a combined form.

The analysis of results reveals that students/future preschool teachers have an expected realistic opinion about the level of openness towards persons with disabilities. $71 \%$ of respondents say that even though the rights of persons with disabilities are regulated by law, they are not applied in practice. $51 \%$ of respondents think that persons with disabilities (deaf persons) can be equally successful in mastering educational programmes at all levels, provided that they mastered their mother tongue already in early childhood, while $49 \%$ do not agree with this statement.

When they were asked to rank by importance the factors influencing pedagogical work of preschool teachers in relation to the integration and appropriate treatment of a deaf child in a group within a preschool institution where the majority of children can hear, about two thirds of respondents/students, more precisely $71 \%$, ranked preparation of other children for the integration of the deaf child as the most important factor. 63\% of respondents/students think that the most important factor for sucessful integration is securing cooperation with experts, members of the team which is providing support for the deaf child. $61 \%$ of respondents/students think that the most important factor for successful integration is to enable the deaf child to learn its mother sign language, and $56 \%$ of them think that in order to have successful integration, the most important thing is to teach the basics of sign language to other children.

When asked what actions they would take if they had a deaf child themselves, $80 \%$ of students/respondents said that they would start learning sign language right away, $1 \%$ would leave it all up to sign language interpreters, and $1 \%$ would ask an expert in the field for advice. $73 \%$ of students/respondents are aware that the sign language is the mother tongue of the deaf, $17 \%$ of them heard/read something about it, and $10 \%$ of respondents said that they didn't know that the sign language is the real natural language of the deaf. When asked whether they think if the deaf child should be included in the regular organized preschool programme, $51 \%$ of respondents think that it is mandatory and extremely important to include a deaf child in the systematic preschool programme with other children, while $39 \%$ of respondents feel the same, but only provided that the child is able to communicate autonomously.

From the analysis of data gathered in this study, it can be deduced, among others, that the students of pre-school teaching studies at our Department have enough understanding for the important issues in the field of the integration of deaf children, young people and adults in the educational system at all levels. 
In defining the competences of the future profession, in accordance with democratic processes around the world, students are open to acquiring new knowledge and new competences by actively participating in team approach to integrate deaf children into regular preschool education.

Given that, education of deaf children in Croatia was performed for a long time by the method of "oral tradition", the sign language was not acknowledged and recognized as an equal language. Expert community should increase efforts in informing the public about the benefits represented by early sign language communication for the comprehensive development of a deaf child. Actually, one of the most important recommendations of the Council of Europe is about offering the possibility to choose a new approach to sign language education for deaf children (Bradarić-Jončić and Tarczay, 2004).

Furthermore, we should take into consideration that the integration of persons with special needs requires a significant social effort to support democratic principles which should be manifested in the regular education system at all levels.

\section{Music accessible to everyone}

If we postulate that the task of civil society is to act in improving conditions for quality integration of deaf and hearing impaired children within the system of educational institutions and the wider community, then music education of a deaf child of early and pre-school age is one of the more important factors in the development of his/her intellectual and other abilities. When talking about music pedagogy and music therapy for the deaf, Mario Rossi noted the connection between speech and singing, and this is why speech development can be identified with development of the ability to sing (Rossi, M., 2001). Appropriate music activities will have an important effect on the comprehensive personality development of every single child, on the development of the child's natural inclination to music, on the improvement of life quality and the choice of the means of communication as well as the easier integration in the community. However, it is extremely important that learning and other organized activities begin at the earliest age. Early inclusion of deaf and hearing impaired children in the preschool institution with other children plays a big role in their successful overcoming difficulties in learning spoken and sign language.

Here we must emphasize that listening process in deaf as well as in hearing children goes through the phase of exploring the source of sound. Listening activates the sense of sight, because as they observe the source of sound (object, instrument), children acquire useful insights and come to certain conclusions independently. The child is often happy to touch and explore the source of sound with the use of entire body and especially his/her hands, often bringing the object to the mouth in order to establish as close a contact as possible. Bodily perception is extremely important in identifying differences in the process of comparison, which directly affects development of memory and recognition (Cremaschi Troversi, 2001). Thus, we could say that sound perception in both hearing and deaf children begins with "bodily resonance" which 
stimulates the desire to establish a dialogue and begin with primary vocalisation, even when the child is vocalizing non-articulated sounds.

Musical activities influence the development of intellectual and perceptive abilities in deaf children. They are able to use the sense of touch to identify differences in size, shape of musical instruments and ways of playing them, thus learning about certain sound characteristics (duration, volume). Through differences in shape and size of musical instruments, children will learn about their nature, origin, distribution (the use of visual didactic means, as picture books, is advised). Through music, children can learn about the importance of tradition, traditional music, typical instruments, national customs.

Musical activities also stimulate the development of motor skills. For example, reproduction of rhythm patterns, defining time signature and tempo, enables better understanding of the way in which a certain instrument is played through the visual channel and through direct contact by creating vibrations. Furthermore, music can be put into action and linked with dance moves, thus developing child's motor skills.

It is surprising to what extent persons with special needs manage to achieve amazing results, thus fulfilling expectations and criteria imposed by modern society. This is why deaf children, just as hearing children, should be placed in conditions for appropriate and comprehensive education from the earliest age. This will enable their preparation for total integration in the wider society, increase their self-awareness and self-confidence, and simplify their inclusion in the working process later in the future.

\section{Armed with arguments against prejudice and ignorance}

Lahe and Železnik, from the School of Health Studies of Maribor University, agree that communication is a fundamental activity, fulfilling the human need for information, the need to acquire knowledge and experience and to experience emotions. Communication is also closely linked to the learning process. Such communication, followed by the above stated learning process is implemented with ease and simplicity, provided that there is an atmosphere of understanding and trust in the immediate environment (Lahe and Železnik, 2005).

To the specific question "what are musical qualities of a deaf person?" there could be an equally specific answer: they have the ability to perceive vibrations, which makes them predisposed for a good perception of rhythm. Living in the world of silence, they are maximally sensitised and focused on the perception of vibration, therefore it is rightly said that they listen to music with their bodies.

Deaf children are also fond of imitating dance moves and they enjoy it very much, especially if during these activities they are provided with support and guidance of an expert using targeted moves and signs. By observing the expert's moves, they imitate some of them, and they are also able to memorize some more complicated motor activity. 
When provided with timely and adequate education, deaf persons can become excellent musicians. A shining example is the world renowned Scottish percussionist Evelyn Glennie, author of the book entitled "Good vibrations", who started to experience hearing loss in the early school age. Thanks to constant, quality education and tenacity she overcame her situation, and she made up for the lack of this very important sense by exceptional development of her eyesight and a refined sense of rhythm.

\section{Music between challenges, motivation and creativity}

Just as spoken and sign language, music has its own form of expression, its own spoken and written language.

It is a well-known fact that even if a person is able to hear speech/music, that doesn't necessarily mean that he/she understands them. At the risk of sounding strange, it is the same for a deaf person, who can perfectly be able to experience and understand music, without actually hearing it. In the light of this, we can conclude that music is not only about sound-tone. It is a much wider and more complex concept. The complexity of music can equally be found in rhythm, time signature, accentuation, music tempo and agogics, and the combination of all these elements determines its ultimate character. Music, which is very often qualified as abstract art, almost always brings concrete and clear content to the listener. This is especially obvious when music links up with lyrics, moves and performing arts (opera, ballet).

When it comes to research work and creativity, communicating through music can become one of the interesting forms of contact of deaf and hearing impaired children with the environment. Children with impaired sound perception usually have above the average developed senses of sight and touch. They are careful observers and they have an excellent memory of all the events in the environment. They perceive vibrations by touch and are able to differentiate among their particularities and differences, which completes their knowledge at the source of these vibrations, i.e. the vibrating body. Thanks to the silence they are surrounded by, they have the possibility to develop a high degree of concentration. Such concentration enables them to perceive simple and more complex rhythmical patterns undisturbed, to understand them and to reproduce them by using body movements.

By treating human body as a potential instrument for reproducing music, new possibilities of integrating the language of music and other forms of expression open up, and they are recommended by Morini and Rossena in the process of education (Morini and Rossena, 2002). First and foremost, this applies to activities accompanied by music, such as dancing, interpreting rhythm by moving arms, legs or the entire body. Furthermore, playing percussions is perceived as a form of individual and group musical activity, a form of game and communication with the environment, as well as a way of socialisation. 
Music education of deaf children and children with damaged hearing performed through appropriate activities can be a good stimulus for establishing communication with the environment, but at the same time it is a challenge.

When talking about music, it is not enough to consider only the perception of sound or various dynamic differences and progressions, which are necessary components in the process of experiencing music. It is also important to indicate a whole series of elements which are equally important for achieving a complete musical experience during a certain activity. Rhythm occupies a significant role in this process. And that is why rhythm should become the pillar of musical education for children with special needs. Making children open and available to "listening" to the duration and intensity of vibrations of a certain body that produces sound, or a voice during speech (singing) becomes a goal of all musical activities. Deaf and hearing impaired persons should perfect their natural abilities to perceive rhythm by way of targeted excercises and quality education with the guidance of experts educated in the field. According to the characteristics of the vibrating body (volume, softness, hardness of material and others), i.e. intensity of vibrations, we are able to determine volume, duration as well as other sound qualities. Vibrations are basic elements that create rhythmic patterns, i.e. rhythm, which is the only structural element which can be perceived by deaf persons and persons with damaged hearing.

Deaf children's extreme sensibility in perceiving rhythm and metrics is enabled by the state of "silence" which is found in them. This silence is what enables their enhanced, focused and targeted "listening", undisturbed by various sounds originating in the environment. This kind of perception can become very stimulating for engaging more seriously in music, or it can simply become a way of communicating with the environment. Modern society in its majority needs to acquire such an attitude, which is extremely stimulating for the deaf minority.

Through adequate training, deaf persons become skilled in observing their environment, they perfect their ability of quality concentration and understanding, and they develop and perfect the ability to memorize body movements. They learn how to listen to vibrations produced by their own bodies and by surrounding objects. By way of vibrations, they experience music tempo, time signature, accents, more complex rhythmic patterns, and thus, the character of the music.

\section{Conclusion}

Today when ensuring human rights becomes a genuine priority for democratic countries, the question of raising and educating deaf children, young people and adults is closely linked to their fundamental right to a stimulating environment.

A stimulating environment for deaf children of an early, pre-school and primary school age first of all implies appropriate upbringing in their own families and adequately designed preschool and primary school education as an important prerequisite for achieving their complete integration. 
Thanks to a number of studies conducted in many countries all over the world, new models of bilingual education ("bilingual-bicultural education") have been identified. These models recognize sign language as part of deaf persons' identity and as a powerful tool helping deaf children to learn social skills and acquire necessary knowledge in preschool institutions and mandatory elementary school. (As early as in 2003 one of the most important recommendations of the Council of Europe was focused on supporting this approach).

New approach to catering to the needs of the deaf minority call for restructuring the entire educational system and this is why it is so important to make sure that young deaf persons have access to universities supported by sign language interpreter.

The Department of Educational Sciences of Juraj Dobrila University in Pula has had some positive experience in the integration of persons with disabilities in the preschool teachers' course, even though the process was often difficult.

In the field of educational sciences today, a strong trend has emerged to acquiring new knowledge, constituting new disciplines, defining new professions. A new approach is adopted in designing the curricula of university studies for primary school and pre-school teachers. Their quality is evaluated on the basis of new criteria involving openness to introducing new knowledge and competencies in the existing study programmes for pre-school and school teachers. This new approach to the integration of deaf persons in educational institutions is supported by various papers written by Department professors.

Studies focused on the ways in which music affects the early education of deaf children indicate the tremendous importance of music in the life of deaf children, because they experience sound perception as a form of "bodily resonance" and a stimulus to communicate by engaging in primary vocalisation of non-articulated sounds. Results obtained from the opinion pole conducted on students of preschool teaching course about the position of the deaf in society and about the perception of integration of young children in preschool education, speak in favour of a realistic evaluation on respondents'/ students' part about a still unfavourable position of the deaf in society, the need to include deaf children of an early and preschool age in an adequately prepared environment of organized preschool education as well as the need to help future preschool teachers acquire new competencies.

The only remaining question is who defines a stimulating environment for a deaf minority in our society?

\section{Literature}

1. Bradarić-Jončić, S. i Tarczay, S. (2004). Sing language and education of the deaf in Croatia, U: Bradarić-Jončić, S., V., Ivasović (Eds.). Sign language, Deaf Culture \& Bilingual Education, Faculty of Education and Rehabilitation Sciences, Zagreb. 
2. Bradarić-Jončić, S. i Tarczay, S. (2008). Uključivanje prevoditelja za znakovni jezik u redovne škole, U: Prema kvalitetnoj školi Zbornik radova stručno-znanstveni skup s međunarodnom suradnjom, 4. Dani osnovne škole Splitsko-damatinske županije, str.105 -112.

3. Carver, R. (1999). Novi pogledi na školovanje i život gluhih, Hrvatski savez gluhih i nagluhih, Zagreb.

4. Cremaschi Trovesi, G. (2001) Il corpo vibrante - teoria pratica adesperienze di mosicoterapia con bambini sordi, Ed Scienifiche Mag, Roma.

5. Ivasović, V. i Andrijević Gajić (2008). Gluho/nagluho dijete u redovnom obrazovnom sustavu problem ili izazov?, Hrvatski savez gluhih, Zagreb.

6. Ivasović, V.(2007). Svijet djece koja ne čuju, Dijete-Vrtić-Obitelj, broj 47., str. 27-28.

7. Juriša, M. (1994). Hrvatski savez gluhih i nagluhih izrastao je iz Zemaljskog zavoda za gluhonijemu djecu, (str. 77-81). U: 110 godina Zemaljskog zavoda za gluhonijemu djecu, Centar za odgoj i obrazovanje „Slava Raškaj“, Zagreb.

8. Lahe, M., Železnik, D., (2005). Pomen komunikacije s slepim in slabovidnim, U: Zbornik radova Novi komunikacijski izazovi s Međunarodnog znanstvenog i stručnog skupa, Hrvatski pedagoško-književni zbor, Zagreb, Visoka učiteljska škola Sveučilišta u Rijeci, str. 407-411.

9. Maleš, D., Milanović, M. i Stričević, I. (2003). Živjeti i učiti prava, Odgoj za ljudska prava u sustavu predškolskog odgoja, Filozofski fakultet Sveučilišta u Zagrebu, Istraživačkoobrazovni centar za ljudska prava i demokratsko građanstvo, Zagreb.

10. Morini, L., Rossena R., (2002). Giocare con i suoni e con il corpo, La Scuola, Brescia.

11. Neal Mahshie, Sh., (1995). Educating deaf children bilingually, Pre-College Programs, Gallaudet University, Washington, D.C.

12. Neal Mahshie, Sh., (2007). Dvojezično obrazovanje gluhe djece, s iskustvima Švedske i Danske, Savez gluhih i nagluhih grada Zagreba.

13. xxx: (1999). Nacionalni program odgoja i obrazovanja za ljudska prava, prvi dio, Predškolski odgoj, osnovna škola, razredna i predmetna nastava, srednja škola, D., Goettlicher, (ur)., Nacionalni odbor za obrazovanje o ljudskim pravima, Vlada Republike Hrvatske. 1-2. 49.-55.

14. Pribanić, Lj. (1995). Jezični razvoj djece oštećena sluha (rječnik i gramatika), Logopedija,

15. Rossi, M. (2001). Dal canto alla parola, La musicopedagogia e la musicoterapia per i sordi di Antonio Provolo, F. Angeli, Milano.

16. Rosić, V. i Zloković, J. (2002). Prilozi obiteljskoj pedagogiji, Grafftrade, Rijeka.

17. xxx: (2007). Strategija za izradbu i razvoj Nacionalnoga kurikuluma za predškolski odgoj, opće obvezno i srednjoškolsko obrazovanje, Vican, D, Rakić, V. i Mulanović-Litre, I. (ur), Ministarstvo znanosti, obrazovanja i športa Republike Hrvatske

18. Venturini, F. (2003). Gluho dijete u obitelji i redovitoj školi, Hrvatski savez gluhih i nagluhih, Zagreb.

19. Žunić, Z. (2001). Profesionalnom rehabilitacijom u 21.stoljeće, Državni zavod za zaštitu obitelji, materinstva i mladeži, Zagreb. 


\section{POTICAJNA OKOLINA U ZADOVOLJAVANJU POTREBA GLUHOG DJETETA RANE DOBI}

Prof. dr. sc. Nevenka Tatković, Odjel za odgojne i obrazovne znanosti Sveučilište Jurja Dobrile u Puli (Hrvatska) e-mail: ntatkovic85@gmail.com

Mr. sc. Aida Muradbegović, Odjel za odgojne i obrazovne znanosti Sveučilište Jurja Dobrile u Puli (Hrvatska) e-mail: aida.muradbegovic@optinet.hr

Marija Crnčić - Brajković, prof. Odjel za odgojne i obrazovne znanosti Sveučilište Jurja Dobrile u Puli (Hrvatska) e-mail: crncicbrajkovic@yahoo.it

\section{Sažetak}

Rani razvoj i stjecanje iskustva događa se u komunikaciji, prostoru i vremenu, a ti čimbenici su specifični kod gluhog djeteta i stvaraju smetnje u strukturiranju njegove osobnosti.

Jedno područje ličnosti istodobno utječe na cjelinu razvoja pa je cjeloviti pristup u odgoju gluhe djece rane dobi načelo odgoja za zaštitu jednakih prava na odgoj i obrazovanje kulture manjine.

Istraživanja znanstvenika pokazala su da gluhoća sama po sebi ne utječe negativno na razvoj djetetovih socijalnih, emocionalnih i kognitivnih sposobnosti, ali nemogućnost komunikacije može izazvati teškoće u svim razvojnim područjima. Fenomen gluhoće nije ograničavajući faktor. Pojedine gluhe osobe dosegle su vrhunske rezultate u različitim područjima znanosti, umjetnosti i stvaralaštva.

Osim teorijskog pristupa problemu, u radu se prezentiraju rezultati empirijskog istraživanja. Cilj je bio istražiti stavove i mišljenja studenata/budućih odgojitelja o njihovoj percepciji statusa gluhog djeteta u društvu i integraciji u redovitu predškolsku ustanovu.

Rezultati istraživanja pokazuju prisutnost niza predrasuda i određenu razinu kritičnosti studenata o potrebi integracije gluhe djece u skupinu većine.Nije osviještena potreba stjecanja novih kompetencija odgojitelja predškolskog odgoja za rad s djecom $\mathrm{s}$ posebnim potrebama $\mathrm{u}$ duhu proklamiranih dokumenata o pravima na odgoj $\mathrm{i}$ obrazovanje.

Ključne riječi: poticajna okolina, gluho dijete rane dobi, studenti, bilingvalno-bikulturalni pristup, kompetencije odgojitelja 